\title{
МІЖКУЛЬТУРНА КОМУНІКАЦІЯ ЯК СПОСІБ СПІЛКУВАННЯ
}

\begin{abstract}
О.М. Кулакова
Сучасний процес глобалізації та інтенсифікації міжнаціонального спілкування став причиною формування ідеї ціннісного плюралізму і культурного релятивізму та поставив у зв'язку з цим завдання формування толерантних відносин між людьми, які репрезентують різні культурні світи. Поняття «міжкультурна комунікація» сьогодні трактується дуже широко і включає різні рівні- від міжособистісного спілкування представників різних соціальних груп із культурними світами, що відрізняються один від одного, до взаємодії між представниками різних національних культур чи цивілізацій. У зв'язку з цим у даній статті ми намагаємося дослідити проблеми міжкультурної комунікації, підкреслюючи її ціннісні та комунікативні виміри.

$\mathrm{y}$ плані нашого розгляду ключовим $€$ поняття «міжкультурна комунікація». Цим терміном позначається адекватне взаєморозуміння двох учасників комунікативного акту, що належать до різних культур. Адже відомо, що, навіть володіючи мовою, люди не завжди можуть вірно зрозуміти один одного, і причиною часто стає розбіжність культур. Серед різноманітних визначень культури найбільше значення, на нашу думку, для дослідження проблем міжкультурної комунікації мають ті, які підкреслюють її ціннісні та комунікативні виміри. Аналіз літератури свідчить, що сучасне прочитання слова «культура» асоціюється з процесом інтелектуального, духовного, естетичного і морального розвитку, позначаючи позитивний стан суспільства, заснований на визначеному порядку, м'якості вдач, багато в чому збігаючись із терміном «цивілізованість». Насамперед, поняття «культура» вказує на особливості способу життя, цінності, властиві певному суспільству чи групі людей. I саме це має принципове методологічне значення, коли ми досліджуємо ціннісні аспекти міжкультурної взаємодії. Тому виділимо загальні характеристики ціннісного відношення
\end{abstract}

Актуальні проблеми духовності

(Відп. ред.: Я.В. Шрамко)

Кривий Ріг (2005), 389-396 
до світу, на основі яких будується міжкультурна комунікація.

Важливим структурним компонентом особистості, що відіграє в $\dddot{11 ~ ж и-~}$ ттєдіяльності організуючу, спрямовуючу і регулятивну роль, виступають ціннісні орієнтації. Саме вони вбирають у себе в концентрованому вигляді всю соціальну психологію особистості, вказуючи на спрямованість їі прагнень та дій. Для суспільства система стійких ціннісних орієнтацій особистості $є$ показником того, що можна чекати від неї. Про суспільнополітичну позицію особистості, її духовне багатство в цілому можна судити по тому, на досягнення яких цінностей спрямовує вона свої зусилля, які об'єкти для неї найбільш значимі. Приписуючи провідну роль в організації та координації елементів дії «оцінному модусу мотиваційної орієнтації», Т. Парсонс відзначає, що «вірність загальноприйнятим цінностям означає, ... що виконавці дії мають загальні «почуття» на підтримку ціннісних зразків» ${ }^{1}$. Спільне визначення загальних ціннісних зразків, породжуючи, за Т. Парсонсом, почуття відповідальності за виконання деяких обов'язків, потім створює і солідарність між усіма індивідами, взаємно зорієнтованими на загальні цінності.

У зв'язку з цим, важливо виділити ті характеристики культури, на основі яких можлива культурна комунікація. Якщо культура контролює поведінку людей, чи можемо ми називати її репресивною? На думку 3. Фрейда - так. Він описав конфлікт між культурою й інстинктивними основами людської природи. Дійсно, культура часто саме «придушує» наші спонукання, особливо сексуальні, соціально-лінгвістичні, проте не виключає їх цілком. Точніше, вона визначає рамки, у яких можливе задоволення цих спонукань. Іншими словами, вона диктує зручний час, місце і засоби для задоволення людських потреб.

Іншою ключовою характеристикою культури $є$ те, що вона «відбирає» для тиражування тільки визначені аспекти поведінки і досвіду людей (так званий «культурний добір»). Для ілюстрації цього відомий антрополог Р. Бенедикт використовувала аналогію з мовою: «Кількість звуків, що можна відтворити за допомогою наших голосових зв'язок і носоглотки, практично безмежна... Але кожна мова повинна здійснити свою власну селекцію звуків і твердо дотримувати обраного, інакше їй загрожує небезпека стати цілком неприступною для розуміння» ${ }^{2}$. Те ж саме можна сказати і про соціальні інститути. Усі людські суспільства зробили свій вибір культурних форм.

Аналіз показує, що в змісті аналізованого поняття загальновизнаними $\epsilon$ наступні критерії. По-перше, культура розуміється як продукт соціальної (а не біологічної) активності людини. По-друге, усі дослідники

\footnotetext{
${ }^{1}$ Parsons T. The Social System. - N.Y., 1964. - P. 41-42.

${ }^{2}$ Benedict R. Race, Science and Politics. - N.Y., 1947.-C. 13.
} 
визнають її історичний генезис, причому підкреслюється, що кожне нове покоління робить свій внесок, так що культура накопичує, акумулює цінності. По-третє, культура дуже важлива для становлення людської особистості. Необхідно підкреслити, що людина формується завжди як член певної спільності людей, так що становлення людини, якщо відвернутися від біологічних особливостей особистості, - це завжди соціалізація, тобто формування внутрішнього світу людини під впливом норм і цінностей, властивих певному соціальному колективу.

Зрозуміло, що культура є суспільним фактом настільки, наскільки вона $є$ репрезентативною культурою тобто робить ідеї, значення і цінності, діючи в силу їхнього фактичного визнання. Вона охоплює усі вірування, уявлення, світогляд, ідеї й ідеології, що впливають на соціальну поведінку, оскільки вони або активно заперечуються людьми, або користуються активним визнанням. «Усі уявлення, ідеї, світогляд, переконання, вірування та ін., що входять у репрезентативну культуру, є діючими в силу їхнього активного прийняття і пасивного визнання. Іншими словами, це ті ідеї, що у сукупності складають генеральне визначення ситуації нашого життя» ${ }^{3}$.

На нашу думку, вивчення форм повсякденного життя міжособистісних відносин, настроїв і емоцій, поведінкових установок, системи ціннісних орієнтирів і інших аспектів менталітету, порівняння сучасних ментальностей з ментальностями, у яких виявляються і конкретизуються загальні і найчастіше подібні соціальні-економічні та політичні закономірності, являє важливу і цікаву наукову проблему. Особливу методологічну значимість у плані нашого розгляду набуває соціологічний аналіз менталітету, що виступає важливою соціокультурною детермінантою життя.

Ментальність виникала на засадах буденної свідомості, практичного досвіду та соціально-психологічних феноменів і формувалася стихійно. При спільності загальних рис вона мала й регіональну специфіку. Більш високий їі тип формувався під впливом теоретичних та ідеологічних чинників. Включення останніх в загальні соціальні процеси розвитку національної свідомості українського народу мали істотні переваги в тому, що вони вирізнялися більшою цілеспрямованістю, систематичністю, глибшим рівнем і загальністю світосприймання, розумінням спільних національнокультурних цінностей, відображенням істотних і загальнозначущих національних потреб, інтересів та загальносоціальної проблематики.

Поняття менталітету інтерпретується різними авторами досить неоднозначно. Аналіз чисельних визначень вказаного поняття приводить до висновку, що існують принаймі три основні тенденції: зведення цього яви-

\footnotetext{
${ }^{3}$ Ионин Л.Г. Социология культуры: путь в новое тысячелетие: Учебное пособие.М.: Издат. Корпорация «Логос», 2000.- С. 56.
} 
ща до раціональних проявів (як «спосіб мислення народу», як «якість розуму» $)^{4}$; психологічні трактування феномену ментальності («психічний склад» або «психологічний тип» етнічної спільності, «національна психоструктура», «інваріантні прояви психології представників певної культури» $)^{5}$; різного роду спроби комплексного визначення поняття, у яких акцент робиться на філософських, духовних, діяльних проявах даного явища («філософсько-світоглядні координати духовного життя народу, нації», «архетипи психоповедінки спільноти», «стереотипи духовної діяльності», «константи групового світобачення і світореагування» $)^{6}$.

При аналізі конкретних проявів менталітету, як правило, говорять про уявлення, відчуття, цінності, інтереси, моральні і діяльні властивості спільнот, найбільш характерні риси, притаманні етносам і їх окремим представникам. Ментальними характеристиками володіють народ, нація, історична епоха, окремий індивід, як представник етнічної спільності, але не представник, скажімо, якоїсь професії. Тобто, мова йде про людські спільності, які існують як історична цілісність досить тривалий час і накопичують певні риси, які так чи інакше виявляються у суб'єктивному світі окремих представників цих спільностей і у їх поведінці.

Аналіз літератури дає можливість зробити висновок, що менталітет являє собою рівень суспільної свідомості, на якому думка не відділена від емоцій. Люди користуються ментальними звичками і прийомами свідомості, звичайно не помічаючи цього, тобто підсвідомо. Зрозуміло, що саме соціокультурний підхід до аналізу менталітету дає можливість осмислити його як сукупність уявлень, поглядів, «відчувань» спільності людей визначеної епохи, географічної області та соціального середовища, що впливають на історичні і соціокультурні процеси. Іншими словами, менталітет - це деяка інтегральна характеристика людей, що живуть в окремій культурі, що дозволяє описати своєрідність бачення цими людьми навколишнього світу і пояснити специфіку їхнього реагування на нього.

В методологічному відношенні уявляється продуктивним об'єднання історико-психологічного та соціокультурного трактувань цього терміна, тобто розуміння положення людини як частини культури, що являє собою сукупність характерних для даного суспільства основних способів виробництва і взаємодії з природою, діяльності соціальних інститутів і інших регуляторів сучасного життя, а також включає в себе вірування, ієрархію цінностей, мораль, особливості між особистісного спілкування.

\footnotetext{
${ }^{4}$ Теорія та історія світової і вітчизняної культури. - Львів, 1992. - С. 25.

${ }^{5}$ Храмова В. До проблеми української ментальності // Українська душа. - К., 1992. - C. 4

${ }^{6}$ Лисий I. Менталітет і духовна культура українців // Філософська і соціологічна думка. - 1995, №11-12. - С. 16.
} 
Насамперед ми використовуємо пояснювальний потенціал категорії «менталітет» для розмежування «загального» $\mathrm{i}$ «одиничного», системи установок суспільства й особистості. Такий поділ зазначених понять методологічно виправданий і при аналізі сукупності соціокультурних проблем, що виникають при аналізі взаємин особистості. У той же час менталітет це своєрідні установки свідомості, неясні і невербалізовані. Менталітет містить у собі основні уявлення про людину, її місце в природі та суспільстві, і1ї розуміння природи і Бога. При цьому всі ці уявлення логічно несистематизовані та неосмислені, вони пов'язані не стільки зі свідомістю, скільки з підсвідомістю.

Створюючи модель світу, витлумачуючи його і сприймаючи його суть, людина використовує невідрефлексовані враження, уявлення й образи. При цьому менталітет виступає як постійно діючий початок в житті людини. Врешті решт саме менталітет є тим своєрідним ферментом, що стимулює діяльність, а часом і визначає поведінку людини і її ставлення до навколишнього світу. Таким чином, як робочу модель ми використовуємо поняття менталітету як сукупності не цілком усвідомлюваних розумових установок і способів мислення, вірувань і звичок, духовних і ціннісних орієнтирів, психічних особливостей сприйняття дійсності і манер поведінки, властивих певній епосі, визначеній соціальній групі чи окремому індивіду. Зрозуміло, що менталітет виявляється у діях і вчинках людей.

До тих факторів, що визначають менталітет народу (тобто своєрідність його психічного складу, світосприймання, поведінки), входять також релігія і мова. Природно, мова і релігія в різній мірі і по-різному визначають етнічну своєрідність; різна також їхня роль у долях різних народів і в долі одного народу на різних етапах його історії. Мова не $є$ обов'язковою ознакою етносу: існують етноси, що розмовляють кількома мовами, і мови, що використовуються декількома народами.

Таким чином, з'ясовуючи співвідношення особистості та культури, ми дійдемо висновку, що неможливо зрозуміти генезис, становлення особистості у відриві від культури соціальної спільності (малої соціальної групи i, в остаточному підсумку, нації). Бажаючи зрозуміти внутрішній світ росіянина, німця, монгола чи француза, варто ознайомитись з роською, відповідно, німецькою, монгольською, французькою культурою.

3 метою вивчення особливостей міжкультурної комунікації, ми акцентуємо увагу на соціально-практичному аспекті спілкування як специфічному суб'єкт-суб'єктному відношенні та взаємодії, де об'єктом діяльності для кожної людини є інша людина. Причому цей аспект виявляється у формуванні не тільки індивідуального, але і групового, колективного суб'єкта діяльності. Раціональна, вольова, емоційна взаємодія суб'єктів є основою формування спільності почуттів, думок, поглядів, досягнення взаєморозуміння і погодженості дій у групі. Індивід, за теорією Шюца, 
бачить світ частиною узагальнено, у типових його характеристиках, частиною-у його індивідуальних властивостях. У цілому ж це бачення унікальне і неповторне і не гарантує надійного погодженого протікання людських взаємодій ${ }^{7}$.

У своєму дослідженні ми спираємося на вчення А. Шюца про соціальну взаємодію як соціально організований феномен, заснований на уявленнях, що мають певний рівень типовості. Типізуються мотиви учасників, типізуються відповідно до мотивів особистості учасників, сама взаємодія сприймається учасниками як типова. Причому, згідно з концепцією Шюца, чим вище ступінь анонімності та типовості взаємодій, чим більш вони стандартизовані й інституціоналізовані, тим більш узгоджено, успішно, «гладко» протікає повсякденне життя в цілому.

Ми розрізняємо пряме міжкультурне спілкування (безпосередній контакт) і непряме, коли існує між партнерами просторово-часова дистанція. К. Ясперс називає комунікацію «безмежним взаємним перебуванням у бесіді» 8 . Особистий контакт має велику силу емоційного впливу, у ньому діє соціально-психологічний «механізм» зараження та наслідування. Особливу роль відіграє мова і так звана паралінгвістична система інформації (мова міміки і жестів), у якій закріплені визначені соціальні значення.

Особливості міжкультурного спілкування визначаються й особливостями спілкування усередині культури. Комунікативним аспектам культури присвячені роботи Б. Маліновського, Й. Хейзинги, М. Еліаде, де автори розглядають культуру в широкому значенні, як специфічно людський спосіб спілкування. Саме в цьому ключі написана робота Й. Хейзинги «Homo Ludens. Людина, що грає». «Культура, - говорить Хейзинга, це одна з форм гри. До ігрового елементу культурного спілкування треба ставитися більш серйозно, ніж це роблять сучасні люди. Тому багато сучасних людей у порівнянні з дикунами, що розуміли серйозність культурного спілкування, $є$ просто варварами, руйнуючими саму сутність культури. Треба жити, граючи, - оскільки гра - найсерйозніше в житті» ${ }^{9}$.

Підхід до культури як сфери спілкування був здійснений М.М.Бахтіним, В.С. Біблером, Н.А. Побєдою й іншими дослідниками. Наприклад, В.С. Біблер розглядає культуру як унікальний і універсальний спосіб спілкування, причому не тільки в рамках свого соціуму, але й у масштабі всього людства. У ХХ столітті типологічно різні культури (цілісні кристали творів мистецтва, релігії, моральності...) втягуються в один часовий і духовний «простір» дивно і болісно, сполучаються одна 3 одною, майже поборовськи «доповнюють», тобто виключають і припускають одна

\footnotetext{
${ }^{7}$ Schutz A. The Problem of Social Reality. Collected. Papers. - Hague, 1962. - Vol. 1. C. 11-12.

${ }^{8}$ Jaspers K. Die Idee der Universität.-B., 1923.-C. 37.

${ }^{9}$ Хейзинга Й. Homo Ludens. - M., 1992.-C. 30.
} 
одну. Культури Азії, Європи й Америки «юрбляться в тій самій свідомості; їх ніяк не вдається розташувати по висхідній лінії (вище-нижче, краще-гірше) $\gg^{10}$.

Важливо відзначити, що спілкування виникає між суб'єктами, які мають подібності та розбіжності, що діють у різних ціннісних полях. Тому багато проблем спілкування концентруються навколо поняття цінності, пов'язані з потребами й установками, що формуються культурою. Наприклад, в Сполучених Штатах Америки вищими цінностями $є$ демократія, ліберальні свободи, вільне підприємництво, тоді як у Єгипті більше значення мають кланові цінності, пов'язані з дотриманням ісламських правил пристойності. Якщо ми хочемо, щоб спілкування було успішним, ми повинні не тільки усвідомити, що $є$ найбільш цінним для нас, але також, що є цінним для тієї культури, з представниками якої ми вступаємо в контакт. Нам можуть не подобатися ті речі, що уявляються найбільш цінними іншим, але ми повинні визнати важливість цих цінностей для них, а вони - визнати важливість наших цінностей для нас.

Культура може розумітися як форма присвоєння індивідом колективного досвіду. Вона служить для «самодетермінації індивіда в обрії особистості» 11 , але вона також обмежує «волю маневру» цієї особистості в культурному просторі визначеного соціуму. Комуніканту весь час пропонуються готові форми мови, прецедентні висловлення, цитати, стереотипи, жорстко пов'язані з визначеним змістом.

У методологічному плані необхідно розрізняти типи і рівні суб'єктів культури, спілкування між якими можна розглядати як міжкультурне. Можна говорити про культуру нації, субкультуру (молодіжну, кримінальну, контркультуру), а також про культуру окремої соціальної групи, тому спілкування між представниками цих груп містить елементи, що складають міжкультурну комунікацію. До міжкультурного спілкування належить також спілкування між представниками різних цивілізацій як культурних суперсистем.

Із соціальної точки зору зв'язок мови і культури нелінійний: можна зафіксувати приналежність того чи іншого індивіда до етнічної групи за мовною ознакою та походженням, але в реальній практиці використання мов буде множинним. Звичаї, ритуали, традиції, як і мова, також являють собою характерні елементи етнічної культури. А в процесі соціалізації відбувається не тільки залучення до норм, традицій, цінностей, створених у результаті розвитку етносу в одному соціокультурному середовищі, але і навчання уміння, навичок, формування соціальних установок індивідів, що відповідають їх соціальним ролям.

${ }^{10}$ Библер В.С. Культура. Диалог культур // Вопросы философии. - 1989.-№6.C. 32 .

${ }^{11}$ Библер В.С. От наукоучения к логике культуры.-М., 1991.-С.4-9. 
Вивчаючи особливості міжкультурної комунікації, ми дійшли висновку, що акультурація (визначається як процес зміни, що відбувається в результаті контакту груп, що належать до культур з конфронтуючими способами життя, при цьому одна з культур займає домінуюче, інша підлегле становище) тісно пов'язана з проявами етноцентризму. Ми використовуємо поняття етноцентризму як прагнення будь-якої етнічної групи відчувати себе центром, навколо якого обертаються інші групи. Крайня форма прояву етноцентризму, як нам уявляється, це заперечення цінностей культури інших груп, зневага до їхніх звичаїв і традицій. Найбільш розвинутим націям стереотипи культурної діяльності народів, що знаходяться на більш низький сходинці, здаються варварством, і вони намагаються нав'язати їм свої ідеї реконструкції і шляхи руху до цивілізації. Слід зазначити, що всі народи, великі та малі, мають певну схильність до етноцентризму при відтворенні свого минулого, створенні образів героїв, осмисленні месіанської ролі свого народу.

Альтернативою етноцентризму, а може бути і своєрідною формою його прояву, є культурний релятивізм. Суть цієї парадигми, на наш погляд, полягає насамперед у доданні своєрідних неповторних рис в культурі етносу, внаслідок чого передбачається, що інші народи не можуть осягти ані систему цінностей, ані характер взаємодії в рамках тієї чи іншої спільноті.

Отже, при аналізі міжкультурних комунікацій важливо акцентувати увагу на втрачених, в значній мірі, культурологічних. Перспективним уявляється повернення соціально-філософського аналізу до суб'єктивних аспектів людської поведінки, локальних ситуацій повсякденного життя. Відроджувати такий гуманітарний напрямок покликана насамперед соціологія якісного стилю з використанням методів «м'якого» аналізу в дослідженнях мовної комунікації як універсальної символічної системи: аналіз документів, інтерв'ю, включене спостереження, що дозволяє розуміти суб'єктивний стан досліджуваних індивідів, аналізувати значеннєвим образом організований світ культури.

Таким чином, розуміючи культуру як сукупний спосіб життя, ми акцентуємо увагу на її ціннісних і комунікативних вимірах. Розуміючи міжкультурну комунікацію як спосіб суб'єкт-суб'єктного відношення, ми звертаємо особливу увагу на трансляцію культурно-утворюючих норм, цінностей, установок і орієнтацій, своєрідність маргінальних станів представників інонаціональної культури. 